\title{
THE STRUCTURE AND DISTRIBUTION OF GLANDULAR TRICHOMES ON THE STEMS AND LEAVES OF DRUG EYEBRIGHT (Euphrasia stricta D. WOLFF ex J. F. LEHM.)
}

\author{
Elżbieta Weryszko-Chmielewska ${ }^{1}$, Anna Matysik-Woźniak ${ }^{2}$, Dagmara Sadowska $^{1}$ \\ ${ }^{1}$ Department of Botany, University of Life Sciences in Lublin, Akademicka 15, 20-075 Lublin, Poland \\ ${ }^{2}$ Ophthalmology Clinic, Medical University of Lublin, Chmielna 1, 20-079 Lublin, Poland \\ e-mail:elzbieta.weryszko@up.lublin.pl
}

Received: 1.08 .2010

\section{Abstract}

Euphrasia stricta is a medicinal plant being one of the ingredients of "Herba Euphrasiae". Many studies have been devoted to the identification of biologically active substances in the herb of eyebright, but much less research has been done on the constitution of glandular structures of this taxon. This paper relates to glandular trichomes located on the stems and leaves of E. stricta. The trichome structure was examined using light and scanning electron microscopy.

It was shown that the stems of E. stricta were mainly covered by non-glandular trichomes, whereas glandular trichomes were rarely found on them. However, clusters of short capitate trichomes were found to occur in specific epidermal regions on both surfaces of the leaf blades and bracts. On the adaxial leaf surface, glandular trichomes grew only in the grooves above the vascular bundles, while on the abaxial surface in the depressions located in the expanded part of the teeth. The glandular hairs consisted of 1-2 cells of the stalk and a two-celled head. Trichomes with 3- or 4-celled heads were found sporadically. The glandular trichomes functioned non-synchronously, since they differed in head size and the colour of cell protoplasts. The presence of a light secretion was found on the surface and around the trichomes in both fresh and dry plant material.

Key words: Euphrasia stricta, Scrophulariaceae, stem, leaf, bract, glandular trichomes, structure, distribution

\section{INTRODUCTION}

The genus Euphrasia L. (Scrophulariaceae) comprises about 350 species (Fisher, 2004); they include both annual and perennial plants that lead a semi-parasitic life. These species are widespread mainly in the moderate climate of the northern and southern hemisphere as well as in high mountains of the Oceania islands (G u s s a ro v a et al. 2008).
Drug eyebright grows on dry meadows and grassy slopes. It is commonly found throughout Poland ( $\mathrm{Zaj}$ ą c and $\mathrm{Zaj}$ ą c, 2001). Eyebright is an annual plant reaching up to $50 \mathrm{~cm}$ in height. In the conditions prevailing in Poland, it flowers from July to September (R u t k o w s k i , 1998).

The stem of this species is finely haired. The leaves with ovate leathery blades are arranged opposite. There are sharp-pointed teeth on the edges of the blades. The two-lipped corolla, 6-11 $\mathrm{mm}$ in length, is differently coloured. The upper lip is smaller, frequently light violet in colour. The lower lip is white and it is marked by the presence of violet stripes and a yellow spot (J a s i e w i c z, 1965; N a w a r a, 2006; Zemanek and Muzyk, 2008). Drug eyebright (Euphrasia stricta D. Wolff ex J. F. Lehm.) is one of the species that has long been used in therapeutics and phytotherapy (N o w i ń k i 1983). It is an ingredient of herbal remedies used in ophthalmology ( $\mathrm{S}$ t o s s et al. 2000; Dh a rm a and S ingh, 2002). Medicinal raw material is the herb of eyebright (Herba Euphrasiae) comprising stems, leaves, and flowers of several Euphrasia species, among others E. rostkoviana and E. stricta, which are picked before fruit formation. It exhibits antibiotic, anti-inflammatory and antioxidative activity. They are usually applied externally in the form of aqueous extracts in the treatment of conjunctivitis and blepharitis as well as in non-specific complaints described by patients as eye fatigue resulting from, e.g., reading, computer work, staying in the sun (K o z ł o w s k i , 1992). Commercially available drops containing eyebright extract are characterized by their effectiveness in the treatment of conjunctivitis induced by excessive exposure to dust, wind, or pollen grains, and they are well tolerated by patients (S t o s s et al. 2000). Worth mentioning is the fact that to date the 
medicinal literature has not reported any significant toxic or allergic effects of eyebright extracts (Trov a to et al. 1996).

A number of biologically active substances have been identified in the eyebright herb: iridoid glycosides (among others aucubin and catalpol), tannins, phenolic acid, benzoic acid, flavonoids, essential oil, resin compounds, coumarin, phytosterol, and mannitol (Kozłowski and Krajewska, 1982; Matławska et al. 1988; Kozłowski, 1992). Moreover, the presence of genkwanin glycosides has been demonstrated in this herb (M a ł $ł a w s k a$ et al. 1993).

The anatomical features of Euphrasia pectinata leaves were studied in Turkey by $\mathrm{Kap} \mathrm{lan}$ and $\mathrm{In}$ c e o g l (2003). S u pers on (1954) describes some features of the structure of the leaves and stems of $E$. rostkoviana and $E$. stricta. In literature no specific data were found on the distribution and structure of the secretory tissues in the stems of E. stricta. The aim of the present study was to examine the structure and to determine the location of glandular trichomes on the surface of the leaves and stems of E. stricta.

\section{MATERIALS AND METHODS}

Flowering shoots of drug eyebright (Euphrasia stricta D. Wolff ex J. F. Lehm.) were collected in natural stands in the first decade of September 2009. The plants grew on grassy hills of Czechów district in Lublin.

Cross sections were made from fresh leaves, bracts, and stems and they were used to prepare semi-permanent slides viewed under a light microscope. The size of trichomes was measured and their structure and location were determined.

For examination in scanning electron microscope (SEM), stem and leaf segments as well as whole bracts were sampled, which were subsequently fixed in $4 \%$ glutaraldehyde and $0.1 \mathrm{M}$ phosphate buffer with a $\mathrm{pH}$ of 7.0 and at a temperature of $22^{\circ} \mathrm{C}$ for 4 hours. After dehydration in ethanol series and acetone, the plant samples were critical-point dried in liquid $\mathrm{CO}_{2}$. Next, they were coated with gold and examined in a TESCAN/VEGA LMU scanning electron microscope. The trichomes on the surface of dry leaves of E. stricta were viewed and photographed using a Nikon AZ 100 M Multizoom microscope.

\section{RESULTS}

\section{A. Trichomes on stems}

The stem surface of Euphrasia stricta is covered with numerous non-glandular trichomes curved downward (Figs 1 A, 2 A). These trichomes reach a length of 185-390 $\mu \mathrm{m}$. They are alive and composed of 2-3 cells (Fig. 2 E-G). The surface of these hairs is marked by finely striated ornamentation and the presence of short appendages at the base (Fig. 1 B, C, D). Compared to the non-glandular trichomes, many fewer glandular trichomes are observed on the stems. They are many times shorter $(30-35 \mu \mathrm{m})$ than the non-glandular trichomes (Fig. 1 B) and are irregularly distributed. The glandular hairs on the stem are composed of a unicellular stalk and a two-celled head (Figs $1 \mathrm{C}, \mathrm{E}$; 2. H, I). The height of the head is $25-27 \mu \mathrm{m}$, its longer diameter 40-45 $\mu \mathrm{m}$, while the stalk height is ca. $10 \mu \mathrm{m}$. The surface of these trichomes is smooth (Fig. $1 \mathrm{C}$ ). In the head and stalk cells of the glandular hairs, there were observed intensely stained protoplasts indicating the end of secretory activity (Fig. $2 \mathrm{H}, \mathrm{I}$ ).

As regards the secondary structure of the eyebright stem, xylem and phloem showed an arrangement typical of uniform growth, forming tightly packed concentric rings (Fig. 2 A). The dark contents of the vacuoles in many epidermal cells were comprised of anthocyanins that produced a violet colour in the stem (Fig. 2 B-D). The parenchyma cells of the primary cortex were thick-walled (Fig. 2 D, G). Some of them, idioblast cells, contained a dark-coloured secretion (Fig. 2 D). Cells with the dark contents in the vacuoles were also observed in the outer phloem regions and xylem elements adjacent to the pith (Fig. $2 \mathrm{C})$. It is probable that biologically active substances occur in them.

\section{B. Trichomes on leaf blades and bracts}

On the abaxial (lower) surface of the leaf blades and bracts, there were areas covered with numerous glandular trichomes on particular teeth (Figs 3. A, B; $4 \mathrm{~A} ; 5 \mathrm{~K})$. The trichomes consisted of a unicellular stalk with an average height of $8 \mu \mathrm{m}$ and a two-celled head whose average height was $26 \mu \mathrm{m}$. At places, these hairs occurred in great density and were characterized by different head diameters (Figs 3 C, D; 4 C, D). The longer head diameter ranged from $24 \mu \mathrm{m}$ to $42 \mu \mathrm{m}$, averaging $32 \mu \mathrm{m}$.

Traces of secretion were visible both on the surface of the glandular trichomes and in their vicinity. Younger hairs were marked by a smaller head diameter, a thicker cell wall, and chloroplasts with an average size of $2.5 \mu \mathrm{m}$. Older hairs had larger, slightly swollen heads with lighter contents. Thinner cell walls and brighter, much smaller (approx. $1.3 \mu \mathrm{m}$ ) plastids were observed in them. Non-glandular trichomes were rarely found in the abaxial leaf epidermis.

Clusters of glandular trichomes with dried lightcoloured secretion were also visible on the dry leaves of E. stricta. The abundant secretion was deposited between the hairs and on their surface (Fig. 5 K). 

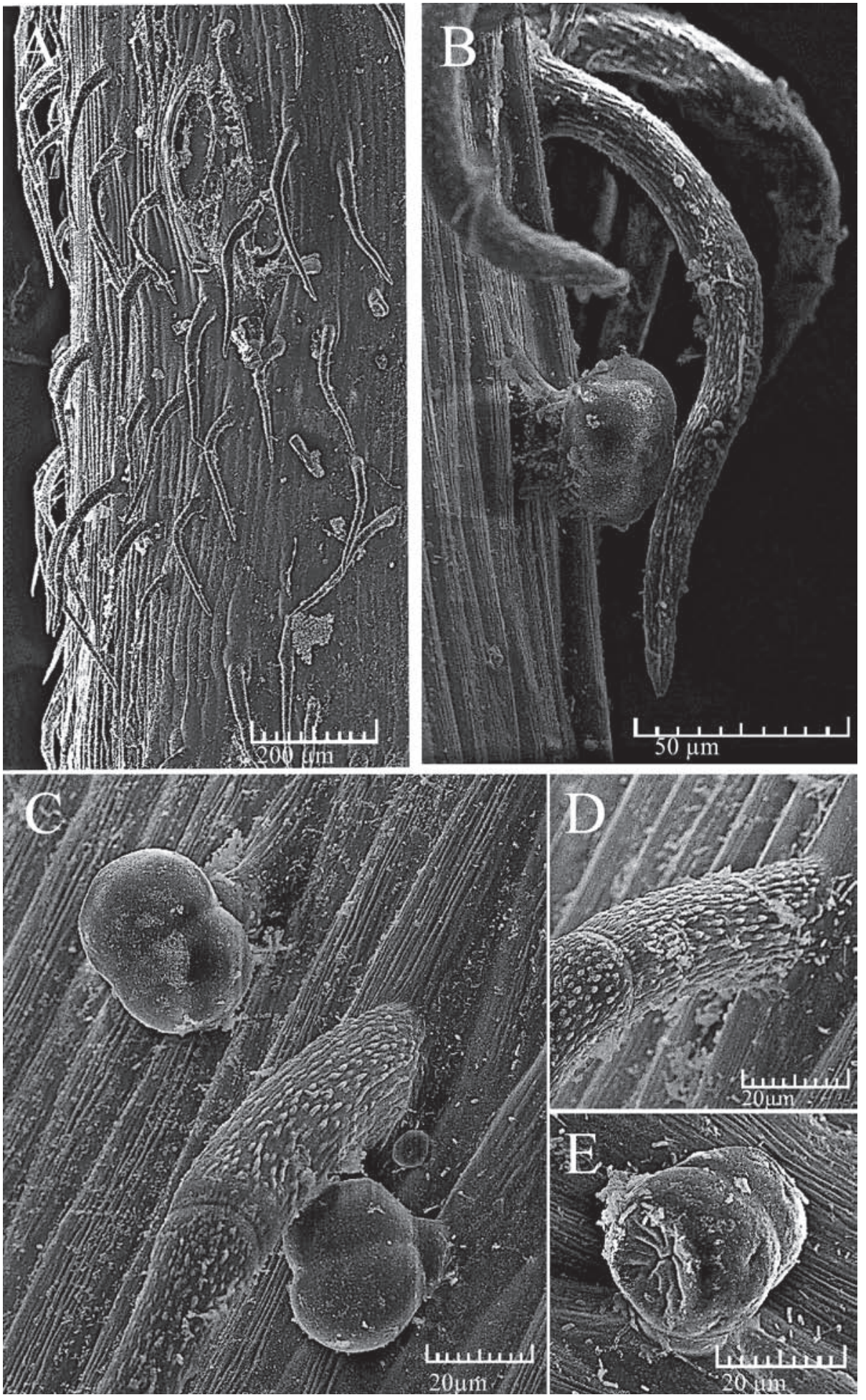

Fig. 1. Surface segments of the stem of Euphrasia stricta (SEM)

A - Non-glandular trichomes are predominant in the stem epidermis

$\mathrm{B}$ - Glandular trichomes are rarely found next to non-glandular trichomes

C - Short glandular trichomes are composed of a two-celled head

$\mathrm{D}$ - The non-glandular trichome base is marked by distinct ornamentation

E - A glandular trichome after secretion release; traces of secretion are visible on the surface 

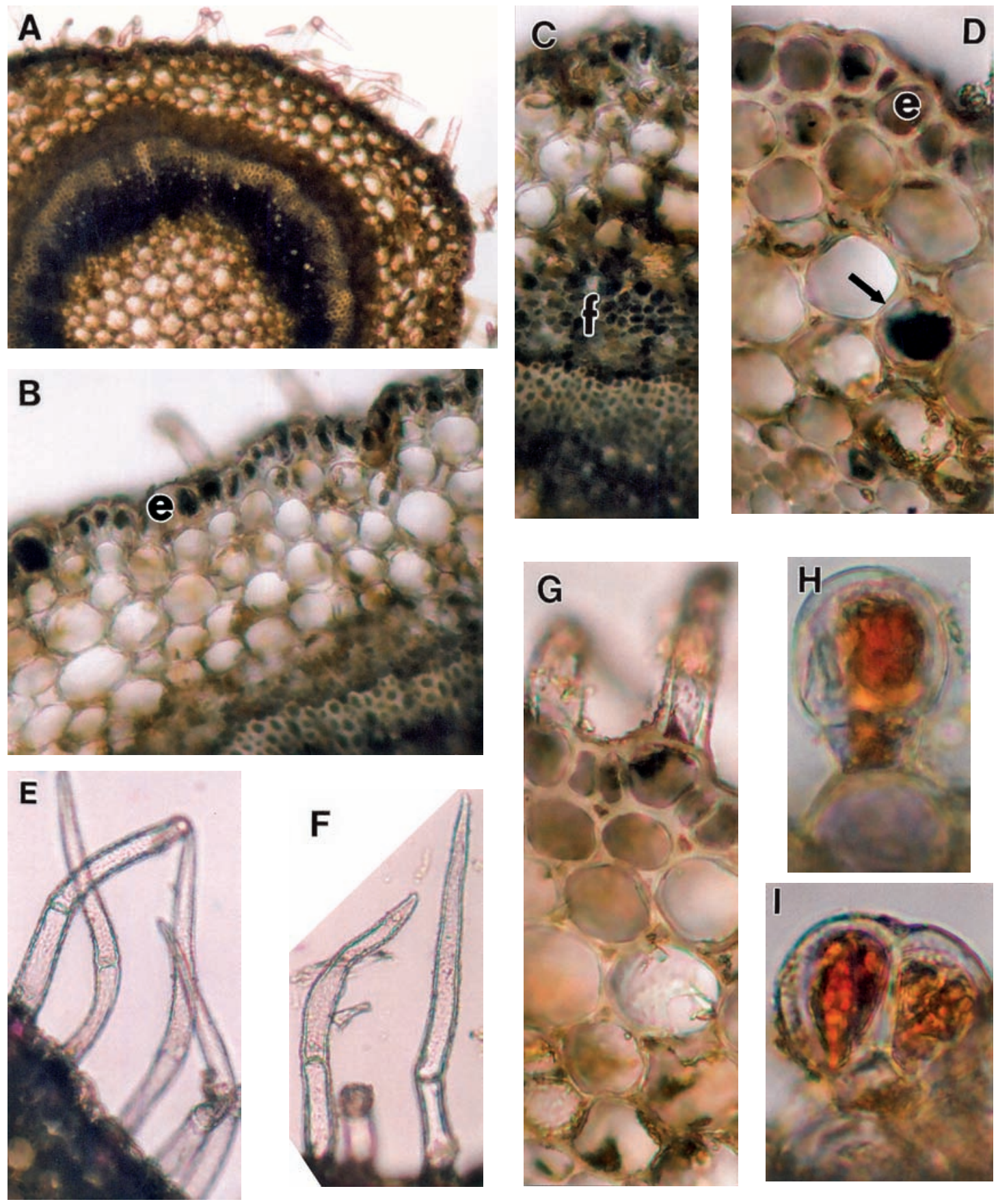

Fig. 2. Cross-section segments of the stem of E. stricta (LM)

A - A large part of the stem cross section is occupied by concentrically arranged xylem and phloem rings, $x 100$

B, C, D - Vacuoles with dark contents are visible in the epidermal cells (e) and parenchyma cells (arrow). Dark protoplasts are also found in the phloem cells (f), B,C - x 300, D - x 500

E, F - Non-glandular trichomes on the stem are composed of 2-3 cells, x 300

$\mathrm{G}$ - Epidermal and parenchyma cells in the primary cortex have thick walls, x 500. H, I- Degenerating glandular trichomes of the stem with resin-coloured contents, x 1000 

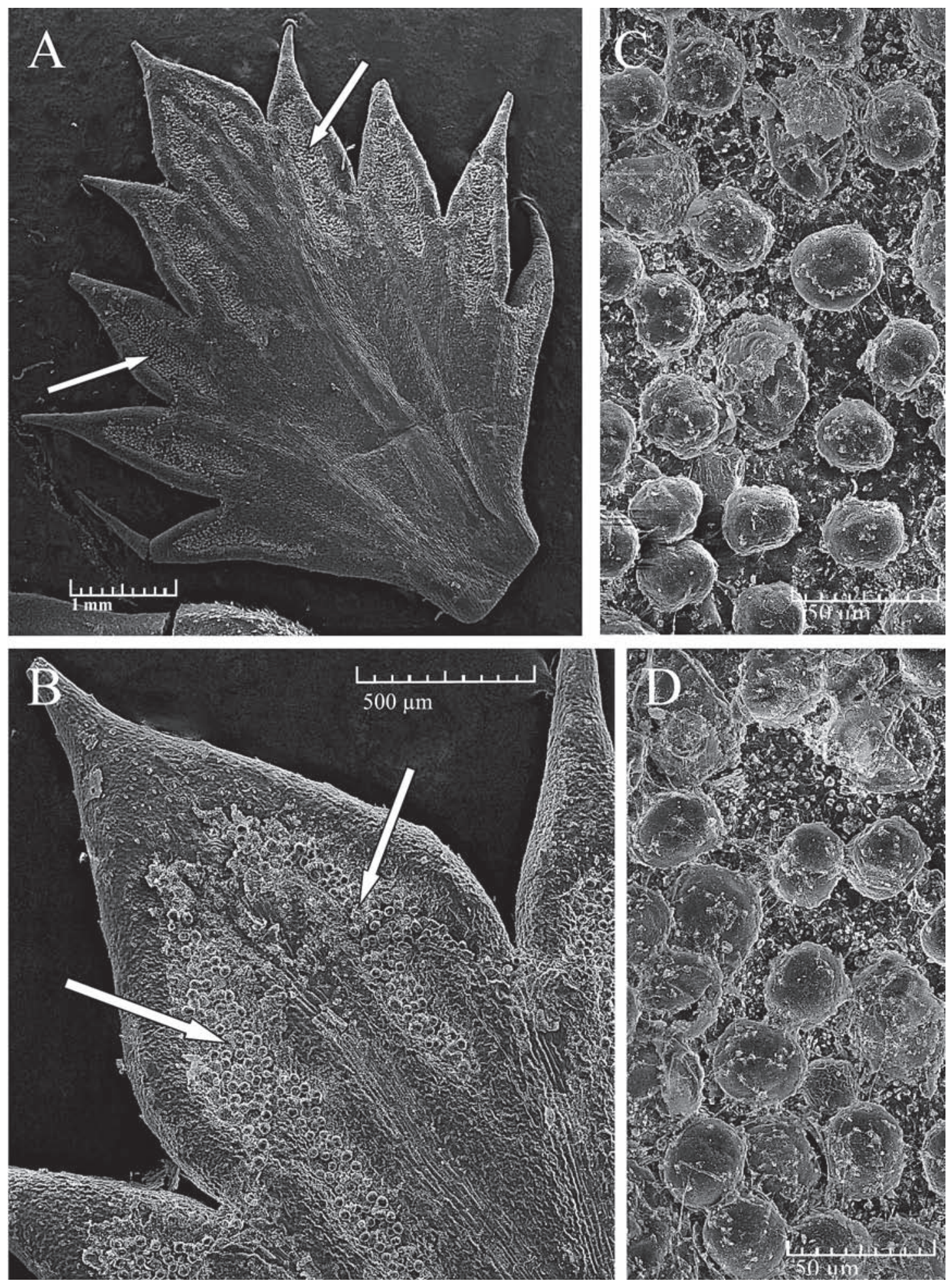

Fig. 3. The abaxial (lower) surface of the bract of E. stricta and its segments (SEM)

A - In the middle part of the tooth surface, there are clusters of glandular trichomes (arrows) forming "glandular fields"

$\mathrm{B}$ - Traces of secretion are visible next to numerous glandular trichomes (arrows)

C, D - A layer of secretion is visible on the surface of many trichomes 

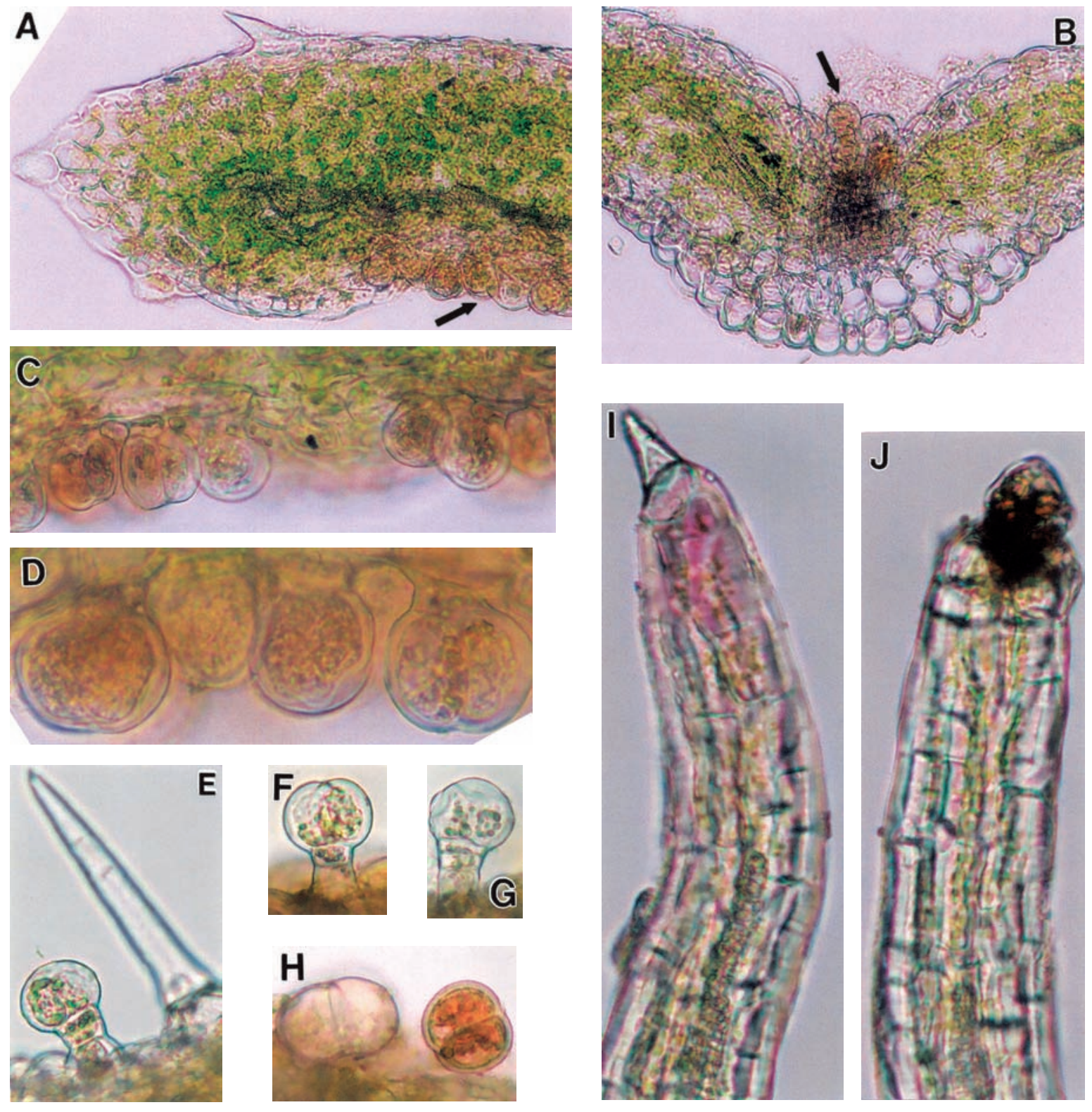

Fig. 4. Cross-section segments of the leaf of E. stricta (LM)

A - The edge region of the leaf with clusters of glandular trichomes located in the depressions of the lower part (arrow), x 200

B - A cross section of the middle part of the leaf with glandular trichomes visible in the epidermis above the bundle (arrow), x 200

C,D - Glandular trichomes from the lower leaf surface, C - x 400, D - x 700

E-H - Trichomes from the upper leaf surface, x 500

I, J - Apical parts of the bract teeth with a non-glandular trichome (I) and a glandular trichome (J), x 20 

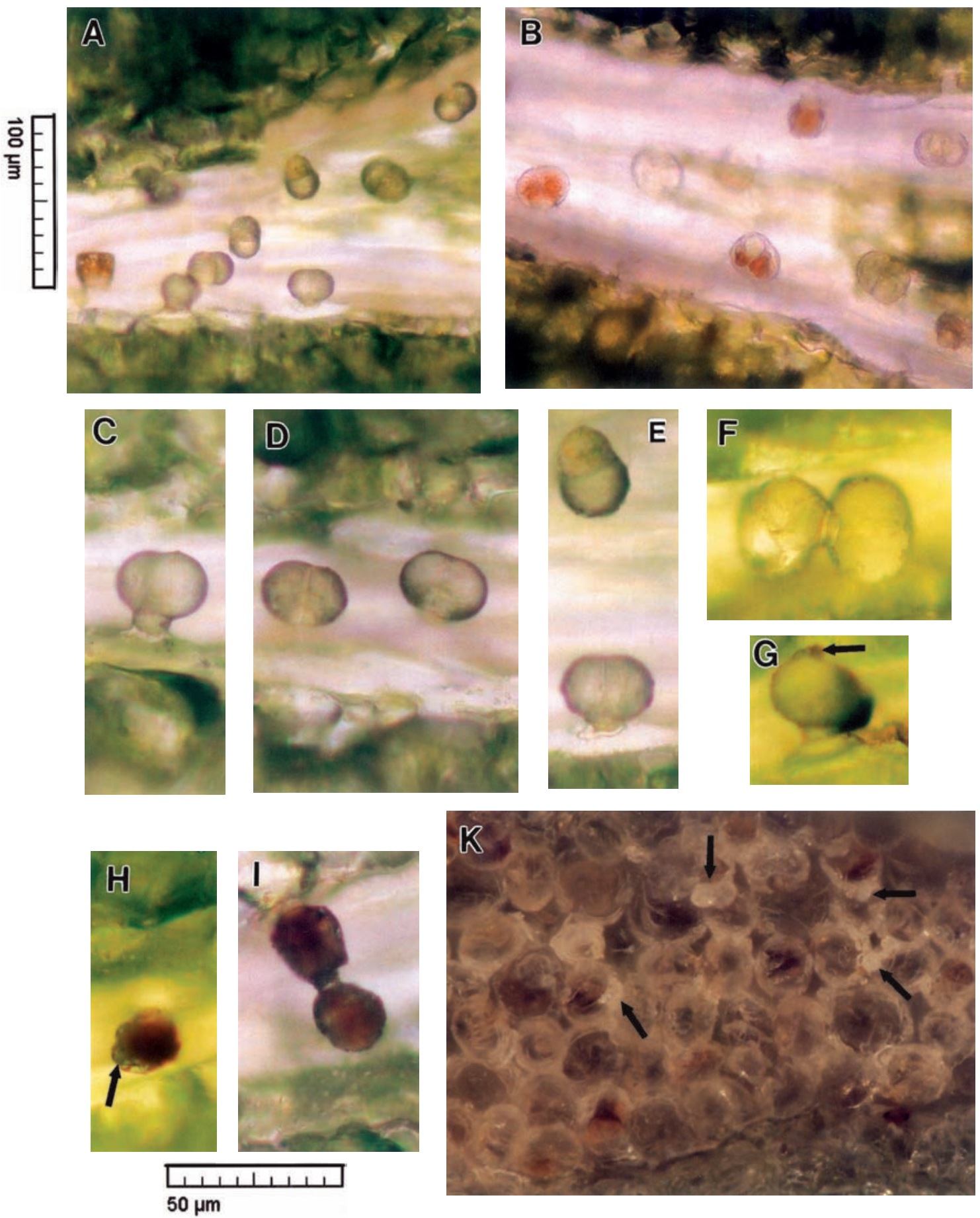

Fig. 5. Glandular trichomes on the upper surface (A-I) and on the lower surface $(\mathrm{K})$ of the bracts of E. stricta (LM). Trichomes in the upper epidermis are located only in the depressions along the veins

A - Younger trichomes on a bract from the upper part of the stem

$\mathrm{B}$ - Older trichomes on a bract from the middle part of the stem

C-E - Glandular trichomes with clearly visible 2-celled heads

F-I - Glandular trichomes at different stages of activity: with the secretion on the surface (arrows), glued together by the secretion $(\mathrm{F}, \mathrm{I})$, degenerating trichomes $(\mathrm{H}, \mathrm{I})$

$\mathrm{K}$ - A segment of a dry bract with numerous trichomes glued together by the secretion which is also found on their surface (arrows) 

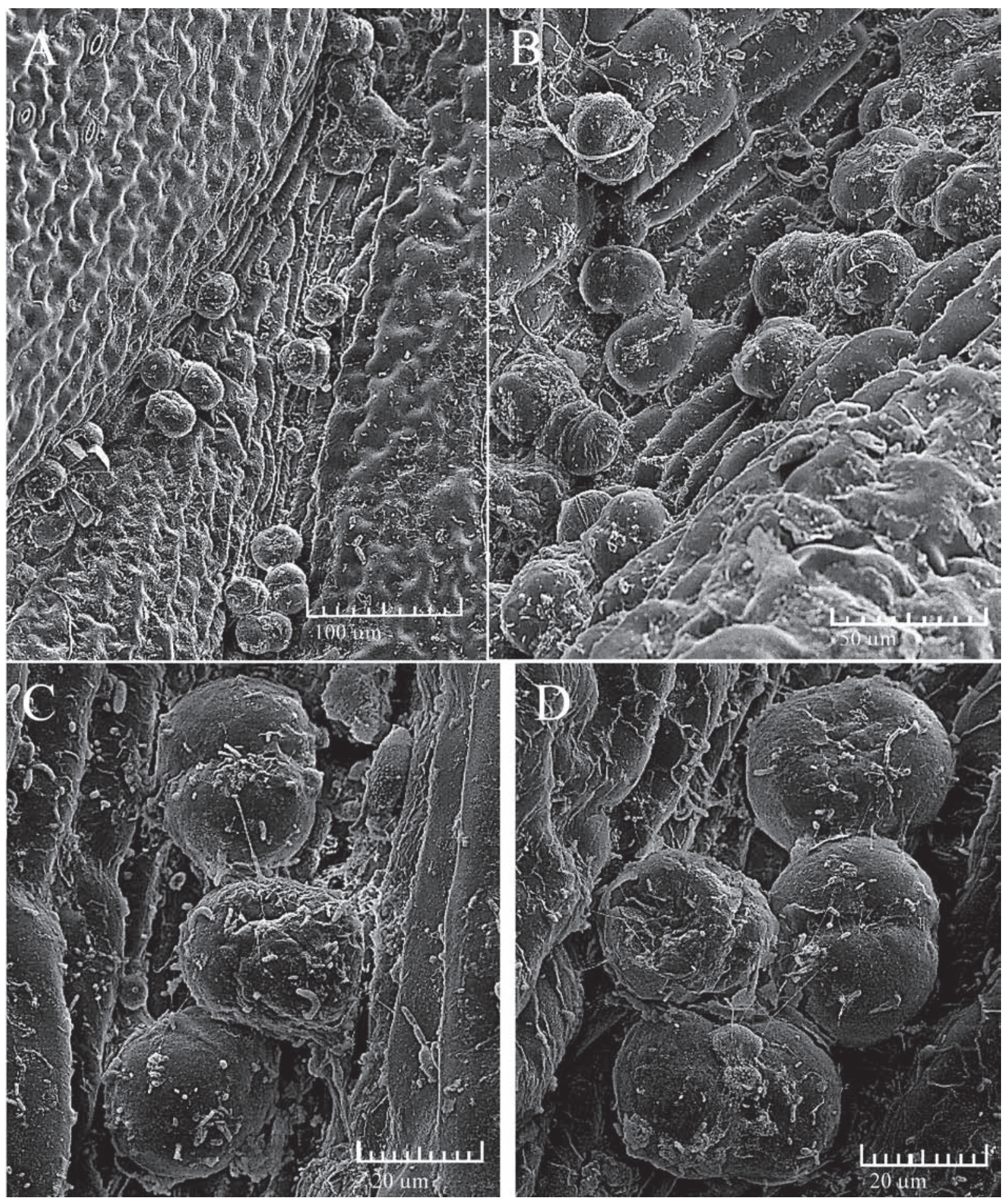

Fig. 6. Glandular trichomes located along the veins on the adaxial leaf surface (SEM)

A - Trichomes growing singly or in small clusters

$\mathrm{B}$ - The secretion is visible on the surface of many trichomes

$\mathrm{C}, \mathrm{D}$ - Trichomes located close to one another are most frequently glued together by the secretion 
On the adaxial (upper) surface of the leaf blades and bracts, glandular trichomes were only found in the epidermis located above the vascular bundles (Fig. 4 B). The leaf venation regions were visible as light-coloured tissue strips due to the absence or smaller amounts of chloroplasts in the mesophyll around the vascular bundles. Therefore, in the fresh leaves viewed in the light microscope, the glandular trichomes were well visible against the bright background of the lower situated tissues (Fig. 5 A-E). The glandular trichomes on the upper leaf surface were found in lower density than in the lower epidermis. They grew singly or formed clusters of 2-4 hairs, less frequently more numerous groups (Figs 5 A, B; 6 A-D). The trichome stalk was composed of one, two, or three cells. The trichomes with a unicellular stalk were lower $(19-30 \mu \mathrm{m})$, with an average height of $26 \mu \mathrm{m}$, while the other hairs $(30-42 \mu \mathrm{m})$ reached an average height of $33 \mu \mathrm{m}$. The stalk length of the lower trichomes was $5 \mu \mathrm{m}$, whereas it was $12 \mu \mathrm{m}$ for the higher trichomes. The head dimensions were similar for both groups of trichomes. The head height was within a range of 16-26 $\mu \mathrm{m}$, on average $22 \mu \mathrm{m}$, whereas the head diameter reached $27 \mu \mathrm{m}$.

Based on the size and colour of the heads of the glandular trichomes, it can be concluded that these trichomes function non-synchronously. Chloroplasts were found in the heads and stalks of the smaller, younger trichomes (Fig. 4 E-G). In the older trichomes, most heads were characterized by light contents with weakly contoured cell organelles (Fig. 4 H). However, in the protoplasts of degenerating, distorted trichomes, orange-brown-coloured contents were observed (Fig. $5 \mathrm{~B}, \mathrm{H}, \mathrm{I})$. In addition to the trichomes with two-celled heads, hairs with heads made up of 3 or 4 cells were also observed sporadically. In many cases, some secretion was visible on the surface of the trichomes (Figs 5 G, H; 6 D) or between them (Fig. 5 F, I).

The non-glandular trichomes occurred individually and rarely in the epidermis of the middle and edge regions of both surfaces of the leaf blades (Fig. 4 A, E). Non-glandular hairs (Fig. 4 I) or glandular hairs (Fig. 4 J) were found on the ends of the teeth of the eyebright leaves and bracts.

\section{DISCUSSION}

Our microscopic observations show that many more glandular hairs occur on the leaves compared to the stems of Euphrasia stricta. The stems are covered mainly with non-glandular hairs, whereas glandular hairs are distributed rarely and irregularly on these organs.

On the adaxial surface of the leaves and bracts, the glandular trichomes grow only in the depressions running along the veins. They occur singly or in small clusters. But on the abaxial leaf surface, the glandular trichomes form glandular fields covering a large area of the teeth. In these places, they form quite dense clusters located in small depressions of the leaf blades.

$\mathrm{K}$ a p l a n and I n c e g l u (2003) described a similar location of glandular trichomes in the grooves on the abaxial surface of the leaves in another representative of Srophulariaceae - Lathraea squamaria.

The size of glandular hairs in E. stricta found on both leaf surfaces differed to a certain extent. The glandular trichomes on the abaxial surface were higher (34 $\mu \mathrm{m})$ and had a larger head diameter $(32 \mu \mathrm{m})$ than the hairs observed on the adaxial surface; their dimensions reached $29 \mu \mathrm{m}$ and $27 \mu \mathrm{m}$, respectively. The glandular trichomes observed on both surfaces of the leaves of E. stricta represented a similar type of structure: a twocelled head was most frequently borne on a short stalk composed of 1-2 cells, sometimes three cells. 3- or 4-celled heads were observed very rarely. S u p e r s o n (1954) as well as K a p l a n and I n c e o g l u (2003) report that glandular trichomes with a 1- or 2-celled stalk and a two-celled head are found in different Euphrasia species, which is in agreement with our observations relating to E. stricta. However, in the investigated species we did not find any blunt-ended, conical glandular trichomes which are reported by S u p e r s o n (1954), or any peltate trichomes recorded by $\mathrm{Kap}$ la $\mathrm{n}$ and In c e o g l u (2003) in E. pectinata.

K a plan and Ince og l u (2003) describe short hairs with a two-celled head found on the leaves of some species from the tribe Rhinantheae in the family Scrophulariaceae: Lathraea squamaria, Melampyrum arvense, Bellardia trixago, and Odontites glutinosa. The cited authors also observed other types of glandular trichomes in the abovementioned species.

A light secretion was observed on many glandular trichomes of E. stricta leaves; it was found not only on fresh leaves but also on dried ones, which allows us to suppose that it was resin. The content of essential oils and resin compounds was found in the herb of this species (Kozłowski and Krajewska, 1982). Oils and resin compounds are secreted through the cellulose walls and the cuticle of the trichome heads onto their surface where the secretion remains or flows onto the surface of the epidermal cells. We observed such a layer of secretion on the surface of the leaves of E. stricta; this secretion frequently glued together neighbouring hairs. E s a u (1973) reports that glandular trichomes release excretions with a different composition of terpenes which are found both in essential oils and resins. B raune et al. (1975) find that the secretions found in trichomes sometimes fill entire cells which exhibit darker contents and die. We observed secretory cells of the trichomes, containing dark 
orange protoplasts, both on the stem and on both surfaces of the leaf blades.

Currently there is a great demand for natural medicines. Patients trust herbal medicines and readily use them. Knowing the exact anatomical structure may help in determining the plant parts that are characterized by the highest content of biologically active substances used in therapeutics. Preparations containing eyebright extract could perhaps be an alternative to antibiotics which are today used excessively in ophthalmology.

\section{Acknowledgments}

The authors of this paper would like to thank Dr. Ewaryst Mendyk and Mr. Krzysztof Skrzypiec, MEng, of the Analytical Laboratory of the Maria CurieSkłodowska University in Lublin for taking photographs with the Nikon AZ 100 M Multizoom microscope.

\section{REFERENCES}

Braune W., Leman A., Taubert H., 1975. Praktikum z anatomii roślin. Państwowe Wydawnictwo Naukowe, Warszawa (in Polish).

Dh arma P., Singh G., 2002. Review of Plant Species Used to Treat Conjunctivitis. Phytother. Res. 16: 1-22.

E s a u K., 1973. Anatomia roślin. Państwowe Wydawnictwo Rolnicze i Leśne, Warszawa (in Polish)

Fis her E., 2004. Scrophulariaceae. [In:] J. W. Kaderait. (ed.), The Families and Genera of Vascular Plants, 7. Flowering Plants. Dicotyledones: Lamiales. Springer-Verlag, Berlin: 333-432

Gussarova G., Popp M., Vitek E., Brochmann Ch., 2008. Molecular phylogeny and biogeoeraphy of the bipolar Euphrasia (Orobanchaceae): Recent radiations in an old genus. Molecular Phylogenetics and Evolution, 48: 444-460.

Ja siewicz A., 1965. Euphrasia L., Świetlik. Uzupełnienie - Rodzina: Scrophulariaceae, Trędnikowate./ Euphrasia L., Eyebright. Supplement - Family: Scrophulariaceae, Figwort Family. Flora Polska, 10: 7-24 (in Polish).

Kaplan A., Inceoglu O., 2003. Leaf anatomy and morphology of 14 species belonging to the Turkish Rhinantheae (Scrophulariaceae) tribe. Israel J. Plant Sci., 51: 297-305.

Kozłowski J., 1992. Świetliki i ich zastosowanie w lecznictwie. / Eyebrights and their application in therapeutics. Widomości Zielarskie, 4: 17-18 (in Polish).

Kozłowski J., Krajewska A., 1982. Ziele świetlika jako leczniczy surowiec roślinny. / The herb of eyebright as medicinal plant material. Farmacja Polska, 38 (10): 471-474 (in Polish).

Matławska I., Sikorska M., Kowalewski Z., 1988. Związki flawonoidowe w Herba Euphrasiae. / Flavonoid compounds in Herba Euphrasiae. Herba Polonica, 34 (3): 97-102 (in Polish).
Matławska I., Sikorska M., Kowalewski Z., 1993. 4'-0-(2-0- $\alpha$-L-Arabinozydo)- $\beta$-D-Glukozyd Genkwaniny w Herba Euphrasiae. Herba Polonica, 39 (1-2): 53-55 (in Polish).

Nawara Z., 2006. Flora Polski. Rośliny łąkowe. Multico - Oficyna Wydawnicza, Warszawa (in Polish).

Now iń s k i M., 1983. Dzieje upraw i roślin leczniczych. Państwowe Wydawnictwo Rolnicze i Leśne, Warszawa (in Polish).

Rut kow ski L., 1998. Klucz do oznaczania roślin naczyniowych Polski Niżowej. Państwowe Wydawnictwo Naukowe, Warszawa (in Polish).

Schultze W., Zänglein A., Hose S., Kubeczka K. H., Czygan F. C., 1992. Volatiles in flowers of balm (Melissa officinalis L.). [In:] R. M. Harley and T. Reynolds (eds). Advances in Labiatae Science: 357-366. Royal Botanic Gardens, Kew.

Stoss M., Michels C., Peter B., Bentke R., Gort e r R. W., 2000. Prospective Cohort Trial of Euphrasia Single Dose Eye Drops in Conjunctivitis. J. Alternative and Complementary Medicine, 6: 499-508.

Superson J., 1954. Historia i farmakoanatomia Herba Euphrasiae. / The history and pharmaco-anatomy of Herba Euphrasiae. Farmacja Polska, 12: 3-11 (in Polish).

Zają c A., Z ając M. (ed.), 2001. Atlas rozmieszczenia roślin naczyniowych w Polsce. Wydawnictwo Pracowni Chorologii Komputerowej Instytutu Botaniki Uniwersytetu Jagiellońskiego i Fundacji dla Uniwersytetu Jagiellońskiego, Kraków (in Polish).

Zemanek B., Muzyk B., 2008. Atlas roślin. Trędownikowate. Wydawnictwo Koliber, Nowy Sącz (in Polish).

\section{Struktura i rozmieszczenie włosków wydzielniczych na łodygach i liściach świetlika wyprężonego (Euphrasia stricta D. Wolff ex J. F. Lehm.)}

\section{Streszczenie}

Euphrasia stricta jest rośliną leczniczą wyróżnioną jako jeden ze składników „Herba Euphrasiae”. Wiele badań poświęcono identyfikacji substancji biologicznie aktywnych w zielu świetlika, znacznie mniej wiąże się z budową struktur wydzielniczych tego taksonu. Niniejsza praca dotyczy włosków wydzielniczych położonych na łodygach i liściach E. stricta. Badania struktury włosków przeprowadzono przy użyciu mikroskopii świetlnej i skaningowej elektronowej.

Wykazano, że na łodygach, które okryte są głównie włoskami mechanicznymi, rzadko występują włoski wydzielnicze. Natomiast na obu powierzchniach blaszek liściowych i przysadek stwierdzono występowanie skupisk krótkich włosków główkowatych w określonych strefach epidermy. Na powierzchni 
adaksjalnej liści włoski wydzielnicze wyrastały tylko w rowkach nad wiązkami przewodzącymi, natomiast na powierzchni abaksjalnej - w zagłębieniach na rozszerzonej części ząbków. Włoski wydzielnicze składały się z 1-2 komórek trzonka oraz z 2-komórkowej główki. Sporadycznie występowały włoski z główkami 3- i 4- komórkowymi. Włoski wydzielnicze funkcjo- nowały niesynchronicznie, gdyż różniły się wielkością główek i zabarwieniem protoplastów w komórkach. Zarówno w świeżym, jak też suchym materiale stwierdzono obecność jasnej wydzieliny na powierzchni i wokół włosków. 
